\title{
STRATEGIC DEVELOPMENT AS A FACTOR IN ENSURING THE ECONOMIC STABILITY OF A MODERN MARKET ENTERPRISE
}

\author{
Svitlana Birbirenko'
}

\begin{abstract}
The purpose of the paper is to analyse theoretical and methodological aspects of the formation of strategic development as a factor in ensuring the economic stability of a modern market enterprise. Methodology. The study has been carried out based on studying the theoretical and methodological aspects of the formation of strategic planning as a basis for strategic development of the enterprise; types of strategies for the development of a modern market enterprise; analysis of strategic development in the context of economic stability of the enterprise. Results of the research. In the course of research, it has been established that strategic development of the enterprise is impossible without premature drawing up of systematic process of strategic planning of the enterprise. Each individual component of economic stability of the enterprise has been characterized by its options for the use of development strategies. Practical implications. The practical significance lies in obtaining a synergistic effect due to a combination of several development strategies that will help to obtain the desired positive result. Conclusions. Strategic development should be aimed at ensuring the ability of the enterprise to achieve strategic development goals and economic sustainability in particular.
\end{abstract}

Key words: economic stability, strategic development, strategic planning, strategic management, modern market enterprise.

JEL Classification: L25, L26, O12, O21, O40

\section{Introduction}

Modern conditions of entrepreneurial functioning have been characterized by transformational changes and instability of the external environment due to the processes of globalization and international integration. This contributes to the formation of certain difficulties in the formation and provision of conditions for effective management of business entities and requires business managers to constantly adjust the system of strategic management for further development of enterprises and making scientifically sound, effective management decisions in particular. That is why the need to reorient the activities of economic entities to the vector of a qualitatively new direction of economic growth with the concentration of management's influence on improving the efficiency of enterprises and ensuring strategic development is rapidly gaining urgency. Thus, there is an objective need to create a management system for strategic development of the enterprise as a factor in ensuring its economic stability in modern market conditions. The purpose of the study is to analyze the theoretical and methodological aspects of the formation of strategic development as a factor in ensuring the economic stability of a modern market enterprise.

\section{Strategic planning as a basis for strategic development}

The versatility of the external environment of the enterprise and its dynamism necessitate the creation of a comprehensive system of mechanisms for managing the development of the enterprise. This orientation allows you to adequately and timely respond to operating conditions characterized by rapid variability. Given this, the introduction and testing of the theory of sustainable development was an important aspect in the management of economic systems at the micro, mesoand macro levels, which allows: "...to systematically approach the solution of diverse and controversial problems of economic development; to justify the effective strategy of development of the enterprise taking into account features of a condition and possibilities of development of its providing systems; ensure consistency of interaction and balance of interests of stakeholders" (Afonichkin, Zhurova, 2015).

\footnotetext{
Corresponding author:

${ }^{1}$ State University of Intellectual Technologies and Communications, Ukraine.

E-mail: sveta_novickaya@ukr.net

ORCID: https://orcid.org/0000-0003-2355-4949
} 
Implementation of strategic development of the enterprise becomes possible only in the presence of strategic orientation. Strategically oriented enterprise is an economic system, in which the staff has strategic thinking, the company uses a system of strategic planning, which allows you to develop and use an integrated system of strategic plans, and current activities are subject to achieving strategic goals (Muliar, 2013; Fedko, 2000).

Currently, the subject of close attention of foreign and domestic scientists is the concept of strategic development of the enterprise in modern crisis conditions. Theoretical, and methodological, and practical principles of problems of development, strategic orientation and achievement of successful, competitive positions of the enterprise in the market in the western countries have sufficiently covered in scientific achievements of foreign scientists. However, the specific conditions of operation of the Ukrainian enterprises require a more detailed study of theoretical and practical aspects of the concept of strategic development of domestic business (Novytska, Dincheva, 2011).

Defining strategic advantages in setting benchmarks for enterprise development provides a good basis for building a reasonable sequence of actions to implement the concept and form a system of strategic management of the enterprise, which will increase the efficiency of its activities, commercial success and sustainable development of the business entity.

Strategic development of any system is impossible without predetermined stages of strategic planning (Novytska, Orlov, 2015). Modern development of market systems has characterized by different approaches to this task: both classical and modern.

An example of a modern concept is the concept proposed by prof. Kuzmin O.Ye. (Kuzmin, Melnyk, 2002), in which he and his co-author identify nine stages of strategic planning, which are clearly presented in Table 1.
After examining the scientific achievements on the topic of strategic planning, we have drawn conclusions that an acceptable sequence, in our opinion, would be as follows.

Stage I. Formulation of the mission of the enterprise. This stage is important and responsible in the process of developing strategic planning and development. The development of the mission in the future will be crucial for the future of the enterprise, as well as its perception as the external environment and directly by employees (Dovbnia, Naidovska, Khytko, 2011; Sklabinska, 2009).

Stage II. Analysis of the external environment. At this stage, an assessment of external factors over which the company has no direct influence is carried out. External analysis is characterized by three areas: the definition of favourable opportunities, i.e. factors that will help to achieve the goals of the enterprise; identification of threats and identification of danger to the enterprise, i.e. a set of external conditions that create certain obstacles to the expansion of the enterprise in the process of achieving the goal, identify key success factors in the selected business segment (Kuzmin, Melnyk, 2002; Kindratska, 2003).

Stage III. Analysis of the internal environment. At this stage, the assessment of factors that can be managed and controlled by the company, namely the factors that form the company and which are the result of the activities or inaction of its management, is carried out (Volder, 2001).

Stage IV. Defining and formulating the goals of the enterprise. The mission, as a rule, determines the general guidelines of development, the target areas of the enterprise, which together represent the meaning of its existence. At the same time, clearly defined, specific endpoints, which the company aims at and to which it aspires, had fixed in the form of its goals. Goals are the specific state of the individual characteristics of the enterprise, the achievement of which is desirable for him or her and to achieve

Table 1

Systematic process of strategic planning of a market enterprise

\begin{tabular}{|c|l|}
\hline $\begin{array}{c}\text { Stages of strategic } \\
\text { planning }\end{array}$ & \multicolumn{1}{c|}{ Characteristics of the stages of strategic planning } \\
\hline I & Information support \\
\hline II & Establishing the mission and goals of the enterprise \\
\hline III & Choice of methods of analysis of internal and external factors \\
\hline IV & Assessment and analysis of environmental factors \\
\hline V & $\begin{array}{l}\text { Assessment and analysis of factors of the internal environment, which makes it possible to identify the strengths and } \\
\text { weaknesses of the enterprise }\end{array}$ \\
\hline VI & $\begin{array}{l}\text { Forecasting of operating conditions and results of production and economic activity of the enterprise, i.e. prediction of } \\
\text { probable changes in external and internal environment and possible influence on activity of the enterprise }\end{array}$ \\
\hline VII & Use of calculations, substantiation of the most important indicators that most fully characterize the expected strategies \\
\hline VIII & Choosing the optimal strategy \\
\hline IX & Evaluation of the strategy, i.e. establishing compliance with the latter goals and mission of the enterprise \\
\hline
\end{tabular}

Source: (Kuzmin, Melnyk, 2002) 
that his or her activities are aimed (Lepeiko, Khvastovskaia, 2006).

Stage V. Analysis of strategic alternatives and choice of strategy. At this stage, the definition of key strategic economic elements, analysis of the strategic portfolio of the enterprise in order to form an alternative set of strategies for each individual economic element and select the most optimal, are presented (Shevchenko, 2009). The key aspect is the purposeful focus on the use of their advantages.

At the final stage of strategic planning, the company implements the strategy into day-to-day operation by developing a system of current plans.

Strategic planning is characterized as a guiding and coordinating vector in determining the strategic development of the enterprise, helps to focus on solving problems that occur during its operation and directs activities to achieve the intended economic goals to achieve the ultimate overall strategic goal, while having a significant impact on the performance of the enterprise and its efficiency (Dovbnia, Naidovska, Khytko, 2011; Dolan, Lindsey, 1992).

\section{Strategies of enterprise development}

In the modern scientific literature, three variants of strategic development are defined.

Option I. Unchanged. Such a strategy is typical of enterprises that are not characterized by significant dependence on the external environment. These are usually companies with a long product life cycle (aircraft, cars, etc.), health care, education, judicial systems, self-government, etc. However, this strategy is not recommended for long-term use, as the company may lose the ability to self-preservation and survival in competition (Martynenko, Ihnatieva, 2006).

Option II. Internal growth. These strategies are based on market development or product development, either sequentially or simultaneously due to the internal capabilities of the enterprise. All types of internal growth strategies are interconnected and implemented through modification changes in products (innovative transformations/modifications), market system (expansion and development), organizational aspects (restructuring, reconstruction, modernization), changes in technology (innovation, reengineering), personnel policy (advanced training through training, motivation) (Korenitsyna, 2012). This set of strategies has been based on the assertion that the company correctly implements its planned activities and this activity should be developed and expanded.

Scientists Martynenko M.M. and Ihnatieva I.A. suggest that there are four strategies that every enterprise focused on internal growth has to implement: concentration, market development, product development, renewal (Figure 1).
Option III. External growth. According to Otenko (Otenko, 2013), the main types of external growth include: horizontal integration, vertical integration, concentric and conglomerate diversification, which is realized due to organizational changes, which are reflected in various forms of mergers, acquisitions and agreements, i.e. distribution of personnel capacity and investment between different activities, the financial results of which are not directly related (Martynenko, Ihnatieva, 2006).

External growth strategies has been implemented based on attracting external sources of funding and resources (joint ventures, mergers, acquisitions) and may contain contractual aspects with enterprises that are at the initial or final stage of creating the value of this enterprise.

A typical means of implementing external growth strategies is reorganization or its forms - transformation and restructuring (Otenko, 2013).

Most often, the results of the analysis of the external environment push it to external growth: the environment creates organizational conditions that lead to a combination of strengths and opportunities to increase activity in managing the components of the external environment until some of them are included in the enterprise.

Let us define the essence of external growth strategies in more detail (on the basis of elaboration (Otenko, 2013; Sharko, Advokatova, 2013; Dziuba, 2010; Sheleheda, Kasianova, Bersutskii, 2006).

1. Horizontal integration is an association of enterprises that are producers of homogeneous products. Efficiency in this case is achieved due to the scale, which allows to obtain additional competitive advantages, replacement of those products on the market that are a close substitute, an analogue of the products, respectively, as a consequence, to displace competitors.

2. Vertical integration takes place when merging enterprises that produce raw materials, process them, and then independently sell products on the market. In other words, vertical integration is characterized as the process of combining enterprises that carry out successive stages of a single, single production cycle of any product, from extraction of raw materials or materials (resources), their processing (production of finished samples) and selling products to the consumer. In this situation, the efficiency and growth of the enterprise increases due to increased control over suppliers (feedback) or distribution channels of products and services (direct integration).

3. Concentric diversification occurs when merging companies that produce similar products or provide similar services. Concentric diversification companies are actively searching for companies that are largely connected to them through sales channels, markets, resource and technology needs, and so on. Thus, the 


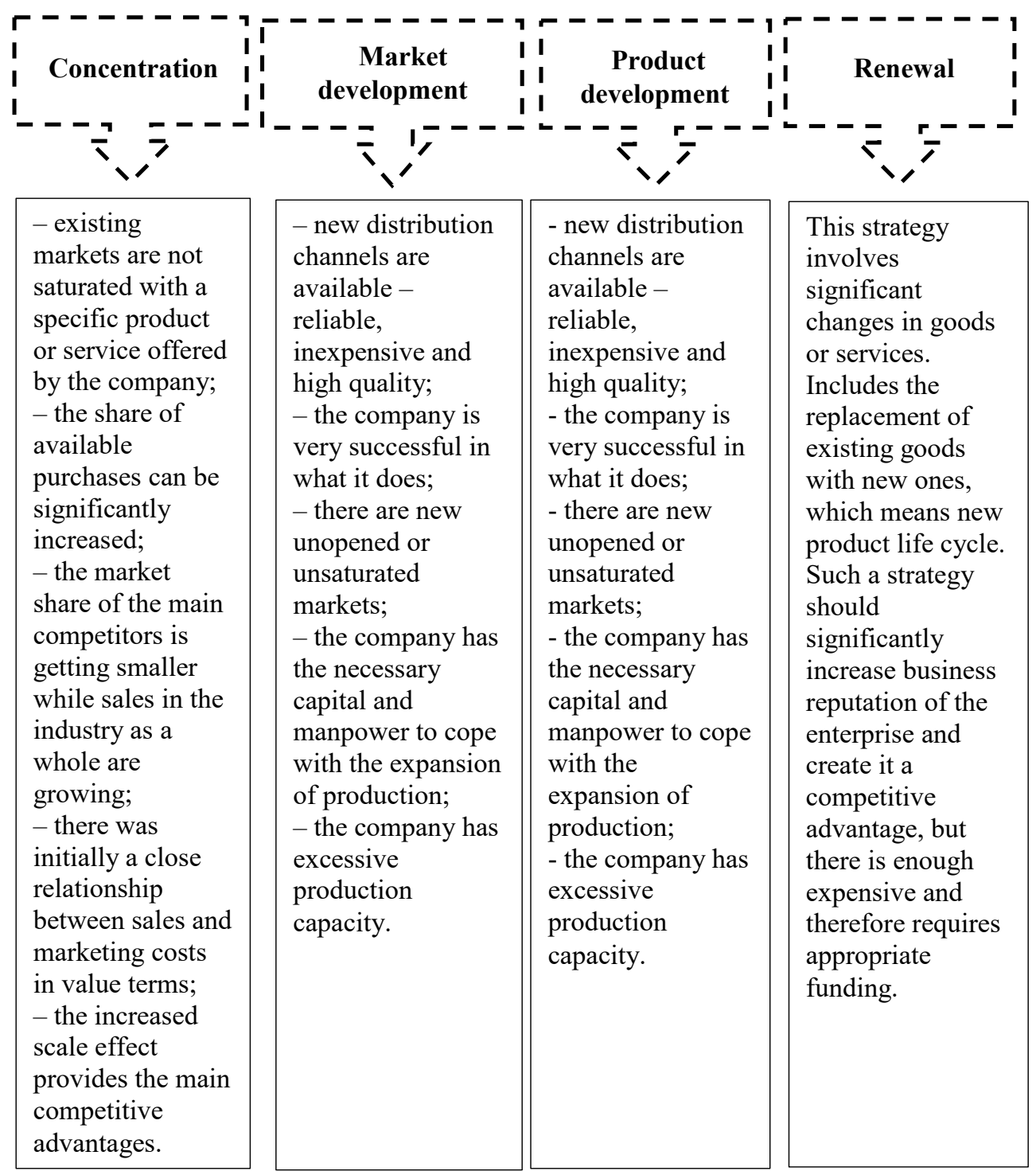

Figure 1. Internal strategies of the enterprise

Source: systematized by the author based on (Martynenko, Ihnatieva, 2006)

existing production continues to be in the center of attention, and the new one emerges from the opportunities that arise in the developed market.

In the implementation of concentric diversification, the company expects that synergistic effect can be achieved due to the presence of several types of activities. The financial benefits of concentric diversification are formed within 2-5 years (Dziuba, 2010).

4. Conglomerate diversification occurs when there is an acquisition of an enterprise that produces such products or provides services that are not related to the products or services of the purchasing enterprise.

Conglomerate diversification provides significant financial synergies. The synergetic effect is manifested in the form of advantages in taxation, greater opportunities for professional development of the enterprise, better use of financial resources, etc. (Dereza, Zhudenko, 2010).
Option IV. Entering the international market. It is planned to introduce measures to represent the commercial interests of domestic businesses in foreign markets.

International business practice identifies three main strategies for entering the international market (Dereza, Zhudenko, 2010):

- Export;

- Creation of a joint venture;

- Direct investment.

Option V. Abbreviation. The decline in activity or withdrawal of investments is a characteristic sign of the cessation of investment, as a result - the consolidation of capital and its subsequent movement.

Reduction strategies take place in crisis situations, when the domestic economy is characterized by recessions and drastic changes. These strategies are always accompanied by losses for the company, but they 
are just as necessary as any other strategy. There are four types of reduction strategies (Sheleheda, Kasianova, Bersutskii, 2006):

- Cost reduction strategy;

- "Harvesting" strategy;

- Reduction strategy;

- Liquidation strategy.

The above strategies are not contradictory, companies can use their combinations to achieve the ultimate goal and change the order of sequence.

\section{Strategic development and economic stability of the enterprise}

Each individual component of economic stability of the enterprise is characterized by its options for the use of development strategies. In addition, you can get a synergistic effect by combining several development strategies, which will help to obtain the desired positive result.

According to (Frolova, Korenitsyna, 2012; Dubrova, 2010), there is the following logical sequence of actions to determine and ensure the economic stability of the enterprise or the stability of its individual components: 1) diagnosis of the current state of stability of the enterprise based on the application of a certain set of indicators;

2) factor analysis of the internal and external environment in order to establish strategic factors of economic stability of the enterprise or its individual components; determination of optimal criteria of stability and substantiation of expediency of their application; determining the level of economic stability (or the stability of its components);

3) search, analysis and testing of certain measures and sources necessary to return the company to equilibrium;

4) development of scientifically sound recommendations for maintaining and increasing the level of economic stability, as well as the implementation of these measures in the daily life of the business entity; control over the process of their implementation.

In the modern scientific community there is an opinion that a high level of economic stability is easier for large enterprises to achieve, because they have sufficient resources and proper ability to quickly adapt to market transformations, forecast their future development, to reduce business risks through market diversification. We fully agree with this opinion because ensuring long-term economic stability requires a sufficient stock of financial resources, our own innovative developments related to production technology, an effective personnel management system, automation of most management processes and control over them.

The key feature of ensuring the economic stability of the enterprise at the present stage of development of society is strategic management, the implementation of which will contribute to the effective functioning of the enterprise in the market environment in the long-term perspective.

Therefore, strategic management should be a tool to ensure the economic stability of the enterprise, the system of which includes a set of alternatives for strategic decision-making depending on the situation at a given time (Tur, 2016).

Strategic management of economic stability of the enterprise should take into account the specific features of each individual production or service sector, as they have significant differences in the levels of concentration of stability in both domestic and foreign markets.

\section{Conclusions}

Ensuring strategic development requires a modern market enterprise to change the profile of activity in the direction of a qualitatively new direction of economic growth, increase the efficiency of its activities. Thus, a necessary condition for ensuring the economic stability of the enterprise is the effective management of its strategic development. Implementation of strategic development of the enterprise takes place only in the presence of strategic orientation.

It is extremely necessary for a modern market enterprise to determine strategic advantages in the formation of directions of development, which will help later in compiling a reasonable sequence of actions for the implementation of the concept and the formation of a strategic management system. All this will increase the efficiency of the enterprise, its commercial success and ensure sustainable development in the future.

Strategic development of any system is impossible without predetermined stages of strategic planning. Strategic planning is a guide and coordinator in the formation of strategic development of the enterprise, allows you to focus on solving tasks and directs activities towards achieving goals.

As an open economic system, the company is characterized by dynamism and operates in conditions of uncertainty (often with a high level) and instability of the market environment. As a result, enterprises are constantly forced to face the negative impact of external factors, which leads to a decrease in its economic stability. That is why the issues of ensuring economic stability have recently been most often considered through the prism of strategic development. However, without ensuring the economic stability of the enterprise to achieve strategic development is impossible. Strategic development should be aimed at ensuring the company's ability to achieve strategic development goals and economic stability in particular. 


\section{References:}

Afonichkin, A. I., \& Zhurova, L. I. (2015). Model otcenki ekonomicheskoi ustoichivosti predpriiatii [Model for assessing the economic sustainability of enterprises]. Basic research, vol. 10 (part 1), pp. 131-136.

Dereza, V. M., \& Zhudenko, M. V. (2010). Formuvannia mozhlyvykh variantiv dyversyfikatsii diialnosti pidpryiemstva [Formation of possible options for diversification of the enterprise]. Economic Bulletin of the National Mining University, vol. 3, pp. 37-43.

Dolan, E. D., \& Lindsey, D. (1992). Rynok: Mikroekonomicheskaia model [Market: Microeconomic Model]. St. Petersburg: Pechatnyi Dvor. (in Russian)

Dovbnia, S. B., Naidovska, A. O., \& Khytko, M. M. (2011). Stratehiia pidpryiemstva: navch. posibnyk, part 1 [Enterprise strategy]. Dnipro: UMetaAU. (in Ukrainian)

Dubrova, O. S. (2010). Stratehichna stiikist pidpryiemstva: skladovi ta napriamy yii zabezpechennia [Strategic stability of the enterprise: components and directions of its maintenance]. Bulletin of Khmelnytsky National University, part 1, vol. 1, pp. 15-19.

Dziuba, O. M. (2010). Rehionalnyi rynok khlibopekarskoi produktsii, novi yoho formy i vydy [Regional market of bakery products, its new forms and types]. Economy. Management. Innovations, [online]. Available at: http://www.nbuv.gov.ua/e-journals/eui/2010_2/10domyfv.pdf

Fedko, V. P. (2000). Rynochnaia ustoichivost promyshlennosti (teoretiko-metodologicheskii aspekt): monografiia [Market stability of industry (theoretical and methodological aspect): monograph]. Rostov on Don.: RGEA. (in Russian)

Frolova, L. V., \& Korenitsyna, T. V. (2012). Intehralna otsinka ekonomichnoi stiikosti torhovelnykh pidpryiemstv Donetskoi oblasti [Integral assessment of economic stability of trade enterprises of Donetsk region]. Proceedings of the International scientific and practical conference (eds. Kupryenko S. V.), T. 19, vol. 2, pp. 80-85.

Kindratska, H. I. (2003). Osnovy stratehichnoho menedzhmentu [Fundamentals of strategic management], second edition. Lviv: KINPATRI Ltd. (in Ukrainian)

Korenitsyna, T. V. (2012). Teoretychne obhruntuvannia poniattia finansovo-ekonomichnoi stikosti torhovelnykh pidpryiemstv [Theoretical substantiation of the concept of financial and economic stability of trade enterprises]. Trade and market of Ukraine: thematic collection of scientific works, vol. 34, pp. 335-343.

Kuzmin, O. Ye., \& Melnyk, O. H. (2002). Menedzhment. Konspekt lektsii: Navchalnyi posibnyk [Management. Lecture notes: Textbook]. Lviv: Publishing House "Lviv Polytechnic National University". (in Ukrainian)

Lepeiko, T. I., \& Khvastovskaia, I. B. (2006). Teoreticheskie osnovy postroeniia modeli strategicheskogo upravleniia predpriiatiem [Theoretical foundations of building a model of strategic enterprise management]. Utilities of cities, vol. 73, pp. 169-176.

Martynenko, M. M., \& Ihnatieva, I. A. (2006). Stratehichnyi menedzhment [Strategic management]. Kyiv: Karavela. (in Ukrainian)

Muliar, T. S. (2013). Formuvannia i realizatsiia stratehii pidpryiemstv [Formation and implementation of enterprise strategy]. Collection of scientific works of Tavria State Agrotechnological University (economic sciences), vol. 2(6), pp. $289-300$. Novytska, S. S., \& Dincheva, V. O. (2011). Vyznachennia definitsii stratehii pidpryiemstva v suchasnykh rynkovykh umovakh [Defining definitions of enterprise strategy in modern market conditions]. Proceedings of the Economics and management in terms of building an information society (Ukraine, Odesa, April 20-22, 2011), Odesa: ONAT named A. S. Popov, pp. 30-33.

Novytska, S. S., \& Orlov, V. M. (2015). Stratehichne planuvannia v protsesi upravlinnia pidpryiemstvom [Strategic planning in the process of enterprise management]. Foreign trade: economics, finance, law, vol. 1(78), pp. 98-105.

Otenko, V. I. (2013). Metodychne zabezpechennia stratehichnykh zmin mashynobudivnykh pidpryiemstv: naukovyi ta prykladnyi aspekty [Methodical support of strategic changes of machine-building enterprises: scientific and applied aspects]. Bulletin of the National University "Lviv Polytechnic" Management and Entrepreneurship in Ukraine: Stages of Formation and Problems of Development, vol. 769, pp. 445-451.

Sharko, M. V., \& Advokatova, N. A. (2013). Razvitie integratcionnykh protcessov i form partnerstva predpriiatii v Ukraine v sovremennykh rynochnykh usloviiakh [Development of integration processes and forms of partnership of enterprises in Ukraine in modern market conditions]. Economic innovations, vol. 53, pp. 332-341.

Shevchenko, O. M. (2009). Vykorystannia metodyky SWOT-analizu dlia rozrobky stratehii derzhavnoho upravlinnia mihratsiinymy protsesamy [Using the methodology of SWOT-analysis to develop a strategy for public management of migration processes]. Actual problems of public administration, vol. 2, pp. 211-219.

Sheleheda, B. H., Kasianova, N. V., \& Bersutskii, A. Ya. (2006). Stratehichne upravlinnia potentsialom pidpryiemstva: monohrafiia [Strategic management of enterprise potential: monograph]. Donetsk: DonUER. (in Ukrainian)

Sklabinska, A. I. (2009). Stratehichnyi analiz u systemi stratehichnoho upravlinnia [Strategic analysis in the system of strategic management]. Bulletin of Khmelnytsky National University, vol. 6, pp. 104-106.

Tur, O. V. (2016). Teoretychni osnovy stratehichnoho upravlinnia i zdiisnennia stratehichnoho planuvannia [Theoretical foundations of strategic management and implementation of strategic planning]. Scientific works of the National University of Food Technologies, no. 4, T. 22, pp. 92-100.

Volder, B. S. (2001). Strategicheskii menedzhment: uchebno-prakticheskoe posobie [Strategic Management: A Study Guide]. Moscow: MFA. (in Russian) 